\title{
Hemşirelik Son Sınıf Öğrencilerinin Kariyer Değerleri ve Kariyer Geleceği Arasındaki İlişkinin Belirlenmesi
}

\section{Determining The Correlation Between Career Values and Career Future of the Fourth-Year Nursing Students}

\author{
Betül SÖNMEZ Merve ÖNAL $^{\mathrm{b}}$ Gözde YILDIZ ${ }^{\mathrm{c}}$
}

ÖZ Amaç: Bu çalışmanın amacı, hemşirelik fakültesinde öğrenim gören dördüncü sınıf öğrencilerinin kariyer değerleri ve kariyer geleceğine ilişkin algılarını, aralarındaki ilişkiyi ve kariyer geleceğine etkili olabilecek faktörleri belirlemektir. Gereç ve Yöntemler: Tanımlayıcı, kesitsel ve ilişki arayıcı tasarımda olan araştırmanın evrenini, İstanbul'da kamuya ait bir hemşirelik fakültesi 2016-2017 eğitim ve öğretim yılında dördüncü sınıfta öğrenim gören ve araştırmaya katılmayı kabul eden 175 öğrenci oluşturdu. Araştırmanın verileri, demografik ve kariyere ilişkin bilgileri sorgulayan soruları içeren tanıtıcı bilgi formu, Kariyer Değerleri Anketi ve Kariyer Geleceği Ölçeği

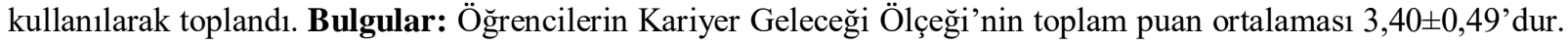

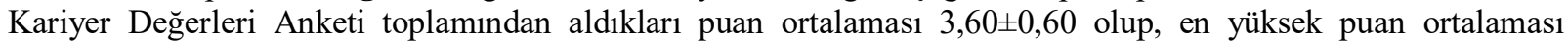
$(3,94 \pm 0,81)$ kendini adama alt boyutunda, en düşük puan ortalaması $(3,35 \pm 0,77)$ meydan okuma alt boyutunda olduğu saptandı. Öğrencilerinin kariyer geleceğine etki edebilecek faktörlerin belirlenmesi amaciyla oluşturulan model kariyer geleceğine ilişkin varyansın \%38'ini açıklamaktadır. Öğrencilerin kariyer geleceği toplam puanı üzerinde güvenlik, otonomi, girişimci ve meydan okuma kariyer değerleri ile üniversite başarısının yüksek olması ve mezuniyet sonrası mesleği yapma isteğinin anlamlı düzeyde etkili olabileceği belirlendi. Sonuç: Hemşirelik öğrencilerinin kariyer geleceği puan ortalaması yüksektir. Öğrencilerin kariyer geleceğine etki edebilecek kariyer değerlerini ve diğer faktörleri ortaya koyan bu çalışma sonuçlarının kariyer danışmanlığı uygulamalarına katkı sağlayacağı düşünülmektedir.

Anahtar Kelimeler: Hemşire, kariyer değerleri, kariyer geleceği, kariyer uyumluluğu, öğrenci

ABSTRACT Objective: The objective of this study is to determine perceptions of the fourth-year nursing students regarding career values and career future, the correlation between them and factors affecting career future. Material-Method: The population of this descriptive, cross-sectional and correlational study consisted of 175 fourth-year students who were studying at a public nursing faculty in Istanbul in the academic year of 2016-2017 and agreed to participate in the study. The data of the study were collected by using the information form including questions regarding demographic and career information as well as Career Anchors Survey and Career Futures Inventory. Results: Total mean score obtained by students from the Career Futures Inventory was 3.40 \pm 0.49 . Total mean score of the Career Anchors Survey was determined as 3.60 \pm 0.60 and while the highest mean score was observed in the subscale of service/dedication to an cause (3.94 \pm 0.81 ), the lowest mean scorewas observed in the subscaleof challenge $(3.35 \pm 0.77)$. The model prepared for determining factors that may affect career future of the students explains $38 \%$ of variance regarding career future. It was determined that security, autonomy, entrepreneur and pure challenge career values, as well as higher university success and desire of implementing the profession after graduation could have a significant effect on total score of students regarding career future. Conclusion:

Geliş Tarihi/Received: 14-04-2018 / Kabul Tarihi/Accepted:26-10-2018

aDr. Öğr. Üyesi, İstanbul Üniversitesi-Cerrahpaşa Florence Nightingale Hemşirelik Fakültesi, Hemşirelikte Yönetim Anabilim Dalı, e-posta: betul.sonmez@ istanbul.edu.tr, ORCID: 0000-0002-6091-4993

bHemşire, SBÜ Bakırköy Dr. Sadi Konuk Eğitim ve Araştırma Hastanesi, Kardiyoloji Kliniği, e-posta: merveonal34@ gmail.com, ORCID: 0000-0001-5654-3045

${ }^{c}$ Hemşire, Kocaeli Devlet Hastanesi, e-posta: gozdeyildiz388@ gmail.com, ORCID: 0000-0003-0171-979X

Sorumlu yazar /correspondence: Betül Sönmez, İstanbul Üniversitesi-Cerrahpaşa Florence Nightingale Hemşirelik Fakültesi, Hemşirelikte Yönetim Anabilim Dalı, e-posta: betul.sonmez@istanbul.edu.tr

*Bu çalışma, sözel bildiri olarak 16. Ulusal Hemşirelik Öğrenci Kongresi'nde (UHOK), 26-28 Nisan 2017 tarihinde İstanbul'da sunulmuştur.

Atıf: Sönmez B, Önal M, Yıldız G. Hemşirelik son sınıf öğrencilerinin kariyer değerleri ve kariyer geleceği arasındaki ilişkinin belirlenmesi. Sağlık Bilimleri ve Meslekleri Dergisi 2019;6(1):126-134

Citation: Sönmez B, Önal M, Yıldız G. Determining the correlation between career values and career future of the fourth-year nursing students. Journal of Health Science and Profession 2019;6(1): 126-134 
Nursing students have a high mean score of career future. It is thought that the results of this study revealing career values likely affecting career future of students and other factors might contribute to career consultancy applications.

Keywords: Nurse, career values, career anchors, career future, career adaptability, student

\section{Giriş}

Bireyin kimliğinin ve toplumsal statüsünün belirlenmesinde etkili olan kariyer, çocukluk döneminden başlayarak tüm çalışma yaşamını etkiler. Kariyer, objektif olarak kişinin yaşamı boyunca çalıştığı pozisyonların tümü, subjektif olarak ise iş yaşamına ilişkin oluşan değer, tutum ve davranışları olarak tanımlanmaktadır. Bireyin kariyer yolunun belirlenmesi amaciyla yapilan kariyer planlamada, bireyin ilgisi, değerleri, yetenekleri vb. açısından kendisini değerlendirmesi ve kariyer gelişimini planlaması sağlanır (1). Bir mesleğe karar verip bu alanda eğitim alan ve iş yaşamına hazırlanan üniversite öğrencilerinin kariyer geleceğini etkileyen faktörleri belirlemek ve bu konuda öğrencilere kariyer danışmanlığ 1 hizmetleri vermenin önemi belirtilmektedir (2). Bireyin tüm hayatını etkileyen kariyerinin doğru şekillendirilmesi, hem bireysel hem örgütsel düzeyde, bireyin en çok sahip olduğu kariyer değerlerinin dikkate alınarak uygun mesleki çevrenin belirlenmesini gerekli kılmaktadır (3).

Super'in Kariyer Gelişim Teorisi'nde, ergenlerin eğitim ya da mesleki seçim yapmaya hazır hale gelmeleri kariyer olgunluğu kavramı ile açıklanmıştır. Daha sonraki çalışmalarda, ergenler için "kariyer olgunluğu" kavramının yerini yetişkinlikte "kariyer uyumluluğu (career adaptability)" kavramının almasi gerektiği belirtilmiştir (4). Savickas (4), kariyer uyumluluğunu, "bireyin bir mesleki role hazırlanırken ya da o role girmek üzereyken karşılaşması muhtemel gelişimsel görevleriyle başa çıkmaya hazır olmasının yanı sıra mesleğin kendisinden ya da çalışma şartlarından kaynaklanan beklenmeyen değişimlerle başa çıkmaya hazır olma gücü” olarak tanımlamaktadır. Uyumluluğun, bireyin kariyerine kararı verme sürecinde ve çalışma dünyasında olan yolculuğunda kritik bir beceriyi temsil ettiği belirtilmektedir (5). Bireyin gelecekteki kariyer gelişimi ile ilgili hep olumlu sonuçlar elde edeceği beklentisi içinde olması ya da olayların en olumlu yönlerine vurgu yapması ve kariyer planlama sürecinde kendini rahat hissetmesi ise kariyer iyimserliği olarak ifade edilmektedir (6). Duffy'nin yaptı̆̆ çalışmada, kariyer uyumluluğu ve kariyer iyimserliği arasında orta düzeyde ilişki saptanmıştır (5).

Tablo 1. Edgar Schein'a Göre Kariyer Değerleri (1)

\begin{tabular}{|c|c|}
\hline Kariyer Değerleri & Bu değerlere sahip olan bireyler için, \\
\hline $\begin{array}{l}\text { Teknik/Fonksiyonel } \\
\text { Yetkinlik }\end{array}$ & $\begin{array}{l}\text { İşe ve göreve yönelik olmak, teknik becerilerini göstermek isteği baskındır. Bu } \\
\text { kisilerde uzmanlık alanında derinlesme ve büvüme önemlidir }\end{array}$ \\
\hline $\begin{array}{l}\text { Yetkinlık } \\
\text { Genel Yönetsel Yetkinlik }\end{array}$ & $\begin{array}{l}\text { Lişılerde uzmanlık alanında derınleşme ve buyume onemlidır. } \\
\text { İdari kabilivetlerini gelistirmek öncelikli is hedefidir. }\end{array}$ \\
\hline Girişimci Yaratıcılık & $\begin{array}{l}\text { Yeni bir ürün veya hizmet üretmek, bilgi ve becerilerini bu amaç için kullanmak } \\
\text { veya yeni işletmeler kurmak önemli özellikleridir. }\end{array}$ \\
\hline Otonomi/Bağımsızlık & $\begin{array}{l}\text { Örgütsel sınırlamalar altında çalışmak istemezler. Başkalarına bağımlı olmak yerine } \\
\text { tek başına çalışmayı tercih ederler. }\end{array}$ \\
\hline Güvenlik/İstikrar & İș ve istihdam güvenliği kariyer seçiminde belirleyici bir etkiye sahiptir. \\
\hline $\begin{array}{l}\text { Hizmet/Bir Olaya Kendini } \\
\text { Adamak }\end{array}$ & $\begin{array}{l}\text { Belli bireysel ve sosyal değerlere saygı, başkalarına yardım ve başarıya adanmışlık } \\
\text { bu değeri yansıtan özelliklerdir. }\end{array}$ \\
\hline Saf Meydan Okuma & $\begin{array}{l}\text { Zor problemlerle uğraşmayı sevmek, rekabetten ve kazanmaktan hoşlanmak bu } \\
\text { değerin varlığını gösterir. }\end{array}$ \\
\hline Hayat Tarzı & $\begin{array}{l}\text { Kariyeri hayatının bir parçası olarak görmek, iş aile ve kendi yaşam tarzı arasında } \\
\text { denge kurmak daha baskındır. }\end{array}$ \\
\hline
\end{tabular}

Kariyer çapaları diğer bir deyiş̧le kariyer değerleri kümesi, "bireyin kişisel değer ve tutumlarından oluşan, onun yaşamını dengeleyen, kendi algıladığı özellik ve yetenekleri, güdü, değer, tutum ve davranışları ile bunları dengeleyen ve yönlendiren unsurlar" olarak tanımlanır. Kariyer 
değerleri kümesi, Schein tarafindan 1970'lerin ortasında beş değer (otonomi/bağımsızlık, güvenlik/istikrar, teknik fonksiyonel yetkinlik, genel yönetsel yetkinlik ve girişimcilik/yaratıcılık) olarak ele alınmasına rağmen, sonraki yıllarda yapılan çalışmalar sonucu bunlara ilave üç değer (hizmet veya bir olaya kendini adamak, saf meydan okuma ve hayat tarzi) daha eklenmiştir (1). Kariyer değerlerinin birbiri ile etkileşim içinde olduğu ve birbirinden kesin çizgilerle ayrılamayacağ bilinmektedir (Tablo 1) (7). Pala (8), Bayram ve ark. (9) ve İbicioğlu ve ark. (10) kariyer değerlerinin cinsiyet, Eyüboğlu (11) yaşanılan bölge, Gezen ve Köroğlu (12) ise mezuniyet sonrası mesleği yapma isteği gibi bazı sosyodemografik özelliklere bağlı olarak farklılık gösterdiğini saptamıştır.

Ülkemizde, öğrencilerin kariyer geleceği (13) veya kariyer değerleri (7-12,14-15) ile ilgili yapılan çalışmalar olmasına karşın, hemşirelik öğrencileri ile yapılmış yalnızca bir çalışmaya (16) ulaşılmıştır. Bu doğrultuda, hemşire öğrencilerin kariyer geleceğine olumlu bir bakış açısı içinde olması, karşılaştığ1 problemlerle daha etkin biçimde baş etmesini sağlamaya yardımcı olacak yöntemlerin belirlenmesinin önemli olduğu ve elde edilen sonuçların kariyer danışmanlığı uygulamalarına yön vereceği düşünülmektedir.

\section{Gereç ve Yöntem}

\section{Araştırmanın Amacı ve Tipi}

Tanımlayıcı, kesitsel ve ilişki arayıcı tipte olan bu çalışmanın amacı, hemşirelik fakültesinde öğrenim gören dördüncü sınıf öğrencilerinin kariyer değerleri ve kariyer geleceğine ilişkin algılarını, aralarındaki ilişkiyi ve kariyer geleceğine etkili olabilecek faktörleri belirlemektir.

\section{Evren ve Örneklem}

Araştırmanın evrenini, İstanbul'da kamuya ait bir hemşirelik fakültesinde 2016-2017 eğitim ve öğretim yılında dördüncü sinıfta öğrenim gören öğrenciler (380 öğrenci) oluşturdu. Gelişigüzel örnekleme yöntemi ile araştırmaya katılmayı kabul eden ve veri toplama formunu eksiksiz olarak yanıtlayan 175 öğrenci araştırmanın örneklemini oluşturdu (yanıtlanma oranı \%46).

\section{Veri Toplama Araçları}

Araştırmanın verileri, Tanıtıcı Bilgi Formu, Kariyer Değerleri Anketi ve Kariyer Geleceği
Ölçeği kullanılarak Şubat 2017 tarihinde toplandı.

Tanıtıcı Bilgi Formu: Bu bölümde, öğrencinin yaşı, cinsiyeti, üniversitedeki başarı durumu, hemşirelik bölümünü kendi isteği ile seçme durumu, mezun olduğunda mesleği yapmayı düşünmesi, mezun olduğunda çalışmayı düşündüğü alan, daha önce kariyer danışmanlığı alıp almadığı gibi demografik ve kariyere ilişkin sorular yer almaktadir.

Kariyer Değerleri Anketi: Kariyer Değerleri Anketi, bireylerin kariyer seçimlerinin nedenlerini tespit etmeyi amaçlayan Schein'ın Kariyer Çapaları Teorisini temel alan ve Eric Jansen ve Gaylen Chandler'in 1990 y1lındaki gönüllü çalışanların kariyer çapalarını belirleyen çalışmada kullanılan anket sorularından oluşturulmuştur (16). Anketin, Türkçe uyarlaması Hakkı Aktaş (15) tarafindan Hava Kuvvetleri Komutanlığ çalışanlarında yapılmıştır. Anketin Türkçe formu, 5'li Likert tipinde yanıtlanan teknik/fonksiyonel, güvenlik/istikrar, otonomi/bağımsızlık, yönetimsel, girişimci, savaşçı, meydan okuma, kendini adama, hayat tarzı olarak 9 alt boyutu içeren kariyer çapalarına ilişkin sorular (28 madde) ile ayrılmaya isteklilik (3 madde) ve kariyer memnuniyetini içeren soruları (3 madde) içermektedir (toplam 34 madde). Ölçeğin 11 boyutu için cronbach alfa değeri 0,62 olarak hesaplanmıştır.

$\mathrm{Bu}$ çalışmada, öğrenci örneklemine uygun olmadığı için ayrılmaya isteklilik (3 madde) ve kariyer memnuniyeti ( 3 madde) alt boyutuna yer verilmedi. Bu nedenle, dokuz alt boyutlu Kariyer Değerleri Anketi'nin faktör yapısının hemşirelik öğrencileri örnekleminde doğrulanması amaciyla doğrulayıcı faktör analizi yapıldı. RMSEA uyum ölçümü 0,096 olup, kabul edilebilir uyum göstermektedir. Diğer uyum ölçülerinden RFI $=0,91$ iyi uyum gösterirken; $\mathrm{NFI}=0,92$; NNFI $=0,95 ; \quad$ CFI $=0,95 ; \quad I F I=0,95 ; \quad S R M R=0,071$ kabul edilebilir uyum göstermektedir. Buna göre uyum ölçülerinin iyi uyum ve kabul edilebilir uyum göstermeleri ayrıca düzeltmeli ki-kare değerinin de $\left(\mathrm{x}^{2} / \mathrm{df}=2,59\right)$ iyi uyum göstermesi, verilerin iyi uyuma sahip olduğu ve modelin istatistiksel olarak anlamlı ve geçerli olduğunu göstermektedir (17). $\mathrm{Bu}$ çalışmada, Kariyer Değerleri Anketi alt boyutlarının cronbach alfa iç tutarlılık değerleri 
0,63 ile 0,77 arasında değişirken; toplam ölçek için 0,94 olarak saptand1 (Tablo 2).

Kariyer Geleceği Ölçeği: Bireylerin olumlu kariyer planlama tutumlarını değerlendirmek amaciyla Rottinghaus ve ark. tarafindan geliştirilen Kariyer Geleceği Ölçeği (KARGEL) Kalafat (6) tarafindan 2012 yılında Türkçe'ye uyarlanmıştır. Ölçek, kariyer uyumluluğu, kariyer geleceği ve iş piyasalarına ilişkin algılanan bilgi olmak üzere 3 alt boyuttan ve toplam 25 maddeden oluşmaktadır ve 5'li Likert olarak yanıtlanmaktadır. Ölçeğin cronbach alfa değeri kariyer uyumluluğu, kariyer iyimserliği ve iş piyasalarına ilişkin algılanan bilgi alt ölçekleri için sırasıyla $0,83,0,82$ ve 0,62 olarak raporlamıştır (6). Bu çalışmada, Kariyer Geleceği Ölçeği'nin alt boyutlarının cronbach alfa iç tutarlılık değerleri sirasıyla $0,85,0,81$ ve 0,55 ; toplam ölçek için 0,88 olarak saptandı (Tablo 2).

\section{Araştırmanın Etik Yönü}

Ölçekleri Türkçeye uyarlayan yazarlardan e-posta aracılığıyla izin alındı. Araştırma için Klinik Araştırmalar Etik Kurulu'ndan etik onay (Tarih: 03.01.2017, Karar No: A-18) ve kurum izni alınd. Öğrencilere anket verilmeden önce çalışma için bilgilendirilmiş olurları alındı ve öğrencilerin araştırmaya gönüllü katılımları sağlandı.

\section{Verilerin Değerlendirilmesi}

İstatistiksel analizler için NCSS (Number Cruncher Statistical System) 2007 (Kaysville, Utah, USA) programı kullanıldı. Kariyer Değerleri Anketi'nin doğrulayıc1 faktör analizi için LISREL 8,8 (Lincolnwood, Illinois, USA) programı kullanıld1. Çalışma verileri değerlendirilirken tanımlayıcı istatistiksel metotlarm (ortalama, standart sapma, medyan, frekans, oran, minimum, maksimum) yanı sıra nicel verilerin karşılaştırılmasında normal dağılım gösteren değişkenlerin iki grup karşılaştırmalarında Student $\mathrm{t}$ testi kullanıldı. Değişkenler arası ilişkilerin değerlendirilmesinde de Pearson korelasyon analizi kullanıldı. Kariyer geleceği üzerine etkili risk faktörlerini saptamada lineer regresyon analizi kullanıldı.

\section{Araştırmanın Sınırlılıkları}

Çalışmada elde edilen sonuçlar, hemşirelik ögrencilerinin öz bildirimlerine dayanmaktadır ve kesitsel bir çalışma olduğu için kariyer değerleri ve kariyer geleceğine ilişkin düşünceleri zaman içinde değişebilir. $\mathrm{Bu}$ durumun yanı sıra çalışmanın yalnızca bir üniversite okuyan hemşirelik öğrencileri ile yapılmış olması da bir sınırlılık olarak değerlendirilebilir.

\section{Bulgular}

Araştırmaya katılan öğrencilerin yaş ortalamas1 21,94 $\pm 0,92$ (min. 21-maks. 26) olup \%84,6's1 kadın, \%15,4'ü erkektir. Öğrencilerin \%50,9'unun üniversite başarı puanının iyi olduğu, \%66,3'ünün hemşirelik bölümünü isteyerek seçtikleri ve \%91,4'ünün mezuniyet sonrası hemşirelik yapmayı düşündükleri bulundu. Öğrencilerin \%15,4'ü kariyer danışmanlığı aldığını belirtti.

Öğrencilerin \%91,4'ü (n=160) mezuniyet sonras1 hemşirelik mesleğini yapmak istemekte olup; en çok cerrahi hemşireliği, kadın hastalıkları ve doğum hemşireliği ve psikiyatri hemşireliğini yapmak istedikleri görülmektedir. Öğrencilerin \%8,6's1 (n=15) mezuniyet sonrası hemşirelik mesleğini yapmak istememektedir; bu öğrencilerin 8'i ne yapmak istediği konusunda kararsızken, 2'si gastronomi alanında, diğerlerinin ise görsel sanatlar, diş hekimliği, tiyatro, siyasi bilimler, ticaret alanlarında çalışmak istedikleri görülmektedir.

Öğrencilerin kariyer değerleri anketi toplamından aldıkları puan ortalaması $3,60 \pm 0,60$ olup, en yüksek puan ortalaması $(3,94 \pm 0,81)$ kendini adama alt boyutunda, en düşük puan ortalamasinın $(3,35 \pm 0,77)$ meydan okuma alt boyutunda olduğu saptand1. KARGEL toplam puan

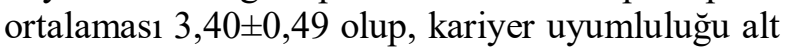
boyut puan ortalamas1 3.51 $\pm 0,57$; Kariyer iyimserliği alt boyut puan ortalamas $3,63 \pm 0,67$; bilgi alt boyut puan ortalamas1 $3,14 \pm 0,64$ 'dür (Tablo 2).

Öğrencilerin KARGEL toplam puanları sosyodemografik değişkenler ile karşılaştırıldığında, cinsiyetleri, hemşireliği kendi isteği ile seçmelerine göre anlamlı farkl11ık saptanmadı $(p>0,05)$. Mezuniyet sonrası mesleği yapma düşünen öğrencilerin KARGEL toplam puanı düşünmeyenlere göre anlamlı olarak daha yüksek bulundu ( $p=0,022 ; p<0,05)$. Üniversite başarısı iyiçok iyi düzeyde olan ögrencilerin KARGEL top lam puanlarının, kötü-orta olanlardan anlamlı olarak daha yüksek olduğu saptandı $(\mathrm{p}=0,002$; $\mathrm{p}<0,01)$. Öğrencilerin Kariyer Değerleri Anketi alt boyutları sosyodemografik değiş̧kenler ile karşılaştırıldığında, cinsiyetlerine göre güvenlik $(\mathrm{p}=0,011)$ 
Tablo 2. Kariyer Değerleri Anketi ve KARGEL Bulguları

\begin{tabular}{lccccc}
\hline & $\begin{array}{l}\text { Soru } \\
\text { sayıs }\end{array}$ & Min-Maks & Medyan & Ort \pm Ss & Zronbach Alfa \\
\hline Kariyer Değerleri Anketi & & & & & \\
Teknik/Fonksiyonel & 4 & $1-5$ & 3,50 & $3,51 \pm 0,68$ & 0,681 \\
Güvenlik/İstikrar & 4 & $1-5$ & 4,00 & $3,73 \pm 0,72$ & 0,779 \\
Özerklik/Bağımsızlık & 3 & $1-5$ & 3,67 & $3,48 \pm 0,77$ & 0,653 \\
Yönetimsel & 3 & $1-5$ & 3,67 & $3,46 \pm 0,74$ & 0,682 \\
Girişimci & 3 & $1-5$ & 3,67 & $3,67 \pm 0,79$ & 0,755 \\
Savaşçı & 3 & $1-5$ & 3,67 & $3,44 \pm 0,77$ & 0,690 \\
Meydan Okuma & 3 & $1-5$ & 3,33 & $3,35 \pm 0,77$ & 0,722 \\
Kendini Adama & 2 & $1-5$ & 4,00 & $3,94 \pm 0,81$ & 0,706 \\
Hayat Tarzı & 3 & $1-5$ & 3,67 & $3,62 \pm 0,68$ & 0,632 \\
Toplam & 28 & $1-5$ & 3,68 & $3,60 \pm 0,60$ & 0,944 \\
& & & & & \\
\hline KARGEL & & & & & \\
Kariyer uyumluluğu & 11 & $1,54-4,72$ & 3,64 & $3,51 \pm 0,57$ & 0,850 \\
Kariyer iyimserliği & 11 & $1,00-5,00$ & 3,73 & $3,63 \pm 0,67$ & 0,817 \\
Bilgi & 3 & $1,00-5,00$ & 3,33 & $3,14 \pm 0,64$ & 0,552 \\
Toplam & 25 & $2,16-4,84$ & 3,40 & $3,40 \pm 0,49$ & 0,887 \\
& & & & & \\
\hline
\end{tabular}

\begin{tabular}{|c|c|c|}
\hline \multirow[t]{2}{*}{ Kariyer Değerleri Anketi } & \multicolumn{2}{|c|}{$\begin{array}{c}\text { KARGEL } \\
\text { Toplam Puanı }\end{array}$} \\
\hline & $\mathbf{r}$ & p \\
\hline Teknik/Fonksiyonel & 0,461 & $0,001^{* *}$ \\
\hline Güvenlik/İstikrar & 0,338 & $0,001 * *$ \\
\hline Özerklik/Bağımsızlık & 0,190 & $0,012 *$ \\
\hline Yönetimsel & 0,451 & $0,001 * *$ \\
\hline Girişimci & 0,543 & $0,001 * *$ \\
\hline Savaşçı & 0,421 & $0,001 * *$ \\
\hline Meydan Okuma & 0,507 & $0,001 * *$ \\
\hline Kendini Adama & 0,346 & $0,001 * *$ \\
\hline Hayat Tarzı & 0,345 & $0,001 * *$ \\
\hline Toplam puan & 0,537 & $0,001 * *$ \\
\hline
\end{tabular}

ve kendini adama $(p=0,006)$ değerlerinde, hemşireliği kendi isteği ile seçmelerine göre teknik/fonksiyonel $(\mathrm{p}=0,017)$ ve kendini adama $(\mathrm{p}=0,015)$ değerinde anlamlı farklılık saptand1. Mezuniyet sonrası mesleği yapma düşüncesine göre teknik/fonksiyonel $(\mathrm{p}=0,026)$ ve güvenlik $(\mathrm{p}=0,008)$ değerinde, üniversite başarısına göre güvenlik $(\mathrm{p}=0,044)$, girişimci $(\mathrm{p}=0,012)$ ve kendini adama $(\mathrm{p}=0,018)$ değerinde anlamlı farkl11ı saptandi.
KARGEL toplam puanı ile Kariyer Değerleri Anketi alt boyut ve toplam puanı arasinda pozitif yönlü istatistiksel olarak anlamlı ilişki saptand1 $(p<0,05) \quad($ Tablo 3$)$. Kariyer geleceği üzerine etkili olabilecek bağımsız değişkenlerden kariyer değerleri anketi alt boyut puanlar1, üniversite başarısı ve mezuniyet sonrası hemşirelik yapmay1 isteme durumu, Stepwice regresyon analizi ile değerlendirildi. Analiz sonucunda model anlamlı bulundu $(\mathrm{F}=15,118 ; \mathrm{p}=0,001)$; beşinci adımda modelin açıklayıcılık katsayısı (R2) 0,388 olarak saptand1. Modelde Kariyer Değerleri Anketi'nin güvenlik/ istikrar, özerklik/bağımsızlık, girişimci ve meydan okuma puanlarının etkileri istatistiksel olarak anlamlı bulunurken $(p<0,05)$; yönetimsel puanı anlamlı olmamakla birlikte modelde yer ald1. Üniversite başarısı ve mezuniyet sonrası mesleğini uygulama isteği yine modelde yer alan anlamlı bir değişken olarak saptandı $(\mathrm{p}<0,05)$ (Tablo 4).

\section{Tartışma}

Öğrencilerin kariyer değerleri ve kariyer geleceğinin incelendiği bu çalışmada öğrencilerin çoğunluğunun hemşirelik mesleğini isteyerek seçtiği saptandi. Daha önce hemşirelik öğrencileri ile yapılan çalışmalar değerlendirildiğinde Karadaş ve ark. (16) benzer şekilde öğrencilerin hemşireliği kendi istekleri ile seçtiklerini saptamıştır. Bununla 
Tablo 4. Kariyer Geleceği Üzerine Etki Edebilecek Değişkenlerin Regresyon Analizi Sonuçları

\begin{tabular}{|c|c|c|c|c|c|}
\hline \multirow[b]{2}{*}{ Model } & \multicolumn{3}{|c|}{$\begin{array}{c}\text { Standardize } \\
\text { edilmemiş katsayı }\end{array}$} & \multicolumn{2}{|c|}{$\% 95$ güven aralığ } \\
\hline & B & $\mathrm{t}$ & $\mathrm{p}$ & Düşük & Yüksek \\
\hline \multicolumn{6}{|l|}{ Kariyer Değerleri Anketi } \\
\hline Güvenlik/İstikrar & $-0,119$ & $-2,056$ & $0,041^{*}$ & $-0,233$ & $-0,005$ \\
\hline Özerklik/Bağımsızlık & $-0,125$ & $-2,340$ & $0,020^{*}$ & $-0,230$ & $-0,019$ \\
\hline Yönetimsel & 0,107 & 1,678 & 0,095 & $-0,019$ & 0,234 \\
\hline Girişimci & 0,230 & 4,129 & $0,000 * *$ & 0,120 & 0,340 \\
\hline Meydan Okuma & 0,216 & 3,871 & $0,000^{* *}$ & 0,106 & 0,327 \\
\hline Üniversite başarısı (İyi ve çok iyi) & 0,064 & 2,082 & $0,039^{*}$ & 0,003 & 0,125 \\
\hline $\begin{array}{l}\text { Mezuniyet sonrası mesleğini uygulamayı } \\
\text { düşünme }\end{array}$ & 0,215 & 1,984 & $0,049 *$ & 0,001 & 0,430 \\
\hline
\end{tabular}

Bağımlı Değişken: KARGEL Toplam Puanı

birlikte, öğrencilerin büyük çoğunluğunun mezuniyet sonrası hemşirelik yapmayı düşündükleri belirlendi. Mezuniyet sonrası çalışmak istedikleri alan sorgulandığında ise sırasıyla cerrahi hemşireliği, kadın hastalıkları ve doğum hemşi-reliği ve psikiyatri hemşireliği olduğu belirlendi. Boroğlu Yatangaç (18) tarafindan bir üniversitenin hemşirelik ve tıp fakültesi öğrencileri ile yaptığı çalışmada, çalışmaya katılan 3 ve 4 . sınıf hemşirelik öğrencilerin en çok genel cerrahi, kadın doğum ve gögüs kalp damar cerrahisi branşını seçmek istedikleri belirlenmiştir. Çalışma alanları tıp branşı şeklinde ele alınmış olmasına rağmen sonucun bu çalışma ile benzer olduğu söylenebilir. Hemşirelik son sınıf öğrencileri ile yapılan bu çalışmada öğrencilerin kariyer geleceği ölçeği puan ortalamasının yüksek olduğu saptandi. İş piyasasına ilişkin algılanan bilgi alt boyutu puan ortalamas1, kariyer uyumluluğu ve kariyer iyimserliği alt boyut ortalamasına göre daha düşük bulundu. Karadaş ve ark. (16) tarafından hemşirelik öğrencileri ile yapılan çalışmada, kariyer uyumluluğu ve kariyer iyimserliğinin yüksek olduğu ve iş piyasasına ilişkin algılanan bilginin ise orta düzeyde olduğu saptanmıştır. Siyez ve Yusupu (2), ölçeğin kariyer uyumluluğu ve kariyer iyimserliği alt boyutlarını kullanarak yaptığı çalışmada, öğrencilerin kariyer uyumluluğu ve kariyer iyimserliğinin yüksek olduğunu saptamışlardır. Kanten (19), Kariyer Uyum Yeteneği Ölçeği kullanarak yaptığı çalışmada, yüksekokul öğrencilerinin kariyer uyum yeteneklerine ilişkin boyut ortalamalarının olumlu düzeyde olduğunu belirtmiştir.

$\mathrm{Bu}$ çalışmada, öğrencilerin KARGEL puan ortalamaları, cinsiyetleri ve hemşirelik bölümünü kendi isteği ile seçmelerine göre anlamlı olarak farklılaşmadı; mezun olduktan sonra mesleği yapmak istemeye ve üniversite başarı düzeyine göre ise anlamlı farklılık saptandı. Karadaş ve ark. (16), öğrencilerin sosyodemografik özelliklerine göre kariyer uyumluluğu ve iyimserliği alt boyut puan ortalamaları arasinda anlamlı farklılık saptamamış ancak cinsiyete göre iş piyasasına ilişkin bilgi ortalamasının anlamlı olarak farklılaştığını belirtmiştir. Kanten (19), öğrencilerin kariyer uyum yeteneği ortalamalarının cinsiyete, bölümü isteyerek tercih edip etmemeye, ileride çalıșmak istenilen alanının bölümle ilgili olup olmamasına ve öğrencilerin büyüdügü sosyal çevreye göre farklılık gösterdiğini raporlamıştır. Kalafat (13), öğrencilerin BEM Cinsiyet Rolleri Envanteri puanına göre KARGEL puan ortalamaları arasinda anlamlı farklılık saptamazken; Siyez ve Yusupu (2), öğrencilerin kariyer uyumluluğu alt boyut puanlarının cinsiyet rolüne göre anlamlı şekilde farklılaştığını saptamıştır. Maskülen ve androjen cinsiyet rolüne sahip olan üniversite öğrencilerinin kariyerde gelecekteki değişimlerle başa çıkma ve bu değişimlerden faydalanma yeteneğini tanımlayan kariyer uyumluluğunun feminen ve belirsiz cinsiyet rolüne sahip öğrencilerden yüksek olduğu belirtilmiştir (2). Bu sonuçlar, çalışma bulgumuzdan farklı olarak cinsiyete veya cinsiyet rolüne göre kariyer geleceğ $i$ puanının farklılaştığını ortaya koymaktadır. 
Öğrencilerin kariyer değerleri ölçek toplamından aldıkları puan ortalaması yüksektir. Puan ortalamas1 3,50'nin üzerinde olan kendini adama, güvenlik/istikrar, girişimci, hayat tarzı ve teknik/fonksiyonel alt boyutları yüksek, diğerleri orta düzeyde olarak değerlendirilebilir. İsrail'de hemşirelikte ikinci kariyer programı olarak iki yıllık eğitim alan ve dört yıllık eğitim alan hemşire mezunlar karşılaştırılmış, iki yıllık eğitim alanlarda teknik/fonksiyonel, dört yıllık eğitim alanlarda ise yönetim, otonomi, kendini adama ve hayat tarzı değeri anlamlı olarak daha yüksek saptanmıştır (20). Pala'nın (8) Spor Bilimleri Fakültesi öğrencileri ile yaptığı çalışmada, Kariyer Değerleri Anketi puan ortalaması $(3,35 \pm 0,78)$ bu çalışma bulgusundan daha düşüktür. Alt boyutlardan güvenlik/istikrarın en yüksek ortalamaya sahip olduğu, en düşük ortalamanın genel yönetsel yetkinlik (yönetsel) alt boyutunda olduğu belirtilmiştir. İktisat ve idari bilimler fakültesi öğrencileri ile yapılan çalışmada, en yüksek ortalamalar güvenlik/istikrar ve girişimcilik /yaratıcılık değerinde, en düşük ortalamalar ise otonomi/bağımsızlık ve teknik/fonksiyonel yetkinlik değerindedir (7). Gergely ve Pierog (21) Avusturya'da ekonomi öğrencilerinin en yüksek kariyer değerini güvenlik, en düşük kariyer değerini ise hayat tarzı olarak saptamıştır. Karakaya ve ark. (14) sporcu öğrencilerin kariyer değerlerinin en yüksek güvenlik/istikrar ve teknik/fonksiyonel, en düşük kendini adama ve ayrılmaya isteklilik değerinde olduğunu saptamıştır. Gezen ve Köroğlu (12), turizm eğitimi alan öğrencilerin teknik/ fonksiyonel yetkinlik, hayat tarzı ve girişimcilik değerinin diğerlerinden daha yüksek olduğunu belirtmiştir. Kariyer değerlerinin eğitim süreleri ile karşılaştırıldığ çalışmada dört y1llık eğitim gören ögrencilerde en yüksek ortalamanın saf meydan okuma değerinde olduğu, bunu kendini adama ve güvenlik değerinin izlediği saptanmıştır (22). İbicioğlu ve ark. (10) çalışmasında ise en yüksek ortalama kendini adama, en düşük ortalama yönetsel yetkinlik değerindedir.

Kariyer değerleri alt boyutlarından güvenlik /istikrar ve kendini adama alt boyutunda kadin cinsiyeti lehine anlamlı farklilık bulundu. $\mathrm{Bu}$ bulgu, çoğunluğunu kadınların oluşturduğu hemşirelik öğrencilerinin güvenlik/istikrar ve kendini adama alt boyutlarındaki yüksek ortalamay1 destekler niteliktedir. İbicioğlu ve ark. (10) benzer şekilde kadınların güvenlik/istikrar, kendini adama ve teknik/fonksiyonel yetkinlik değerinin, erkeklerin ise yönetsel yetkinlik ve otonomi/bağımsızlık değerinin anlamlı olarak daha yüksek olduğunu belirtmiştir. Eyüboğlu (11) 'da benzer şekilde güvenlik/istikrar değerinin kadınlarda, otonomi/bağımsızlık değerinin erkeklerde anlamlı olarak daha yüksek olduğunu saptamıştır. Bayram ve ark. (9) kariyer değerleri ile kişilik özellikleri ilişkisini inceledikleri çalışmasında cinsiyete göre yönetsel yetkinlik ve meydan okuma değerleri dışındaki tüm değerlerin anlamlı olarak farklılaştığını belirtmiştir. Erkek öğrencilerin sadece özerklik/bağımsızlık kariyer değeri puan ortalamas1 k1z öğrencilerinkinden yüksektir. Kula ve ark. (23), sosyal bilimler enstitüsü lisansüstü öğrencileri ile yaptığ 1 çalışmada yönetsel yetkinlik ve girişimcilik/yaratıcılık değerlerinde cinsiyete göre anlamlı farklılık saptamıştır. Gezen ve Köroğlu (12)'nun çalışmasında da, erkek öğrencilerin girişimcilik kariyer değerinin kız ögrencilere göre daha önemli olduğu saptanmıştır.

Hemşireliği isteyerek seçme (teknik yetkinlik ve kendini adama), mezuniyet sonrası mesleğini yapma isteği (teknik yetkinlik ve güvenlik) ve üniversite başarısına göre (güvenlik, girişimci ve kendini adama) bazı kariyer değerlerinde anlamlı farklılık saptandı. Benzer şekilde, Gezen ve Köroğlu (12) turizm bölümünü isteyerek seçtiğini belirten öğrencilerin teknik/fonksiyonel yetkinlik, girişimcilik ve kendini adama değerinde anlamlı farklılık olduğunu saptamıştır. Mezun olduktan sonra mesleği yapma isteğine göre de teknik/fonksiyonel yetkinlik, yönetsel yetkinlik, girişimcilik ve kendini hizmete adama değerinde farkl111ğın anlamlı olduğu bulunmuştur.

Hemşirelik son sınıf öğrencilerinin başarı puanı (iyi ve yüksek olma), mezuniyet sonras1 mesleğini yapmayı düşünme değişkenlerinin, güvenlik/istikrar, özerklik/bağımsızlık, yönetimsel, girişimci ve meydan okuma değerlerinden oluşan doğrusal kombinasyonun kariyer geleceğini anlamlı düzeyde etki edebileceği saptandı. Oluşturulan model kariyer geleceğine ait varyansın \%38'ini açıklamaktadır. Kariyer değerlerinden güvenlik/istikrar, özerklik/bağımsızlık, girişimci ve meydan okuma değerinin etkisinin anlamlı olduğu görüldü. Güvenlik/istikrar, özerklik/bağımsızlık değerlerinin kariyer geleceği üzerindeki etkisi negatif ilişkili iken girişimci ve meydan okuma değerinde 1 birimlik artışın kariyer geleceği puanı üzerinde sırasıyla 0,230 ve 0,216 birim artışa 
neden olduğu belirlendi. Kariyer değerleri ile kariyer geleceği arasındaki ilişkiyi araştıran daha önce yapılmış araştırma sonucuna ulaşılamadığ 1 için kariyer uyumluluğunu etkileyen faktörlere ilişkin yapılan araştırma sonuçları ile karşılaştırıldı. Kalafat (6), öğrencilerin deneyime açıklık ve sorumluluk kişilik özellikleri ile kariyer gelecekleri arasına olumlu ilişki saptamıştır. Yazar, yeni girişimde bulunmaktan korkmayan, sorumluluk sahibi olan bireylerin kariyer geleceklerine ilişkin bakışlarının daha olumlu ve kariyer sürecinde değişimlere daha hazır olduklarını belirtmektedir (6). Jiang (24), Çin'de çalışanların proaktif kişilik, başarılı olma ve kariyer uyumları arasındaki ilişkinin incelendiği çalışmasında, proaktif kişiliğin önce bireylerin işinde başarılı olmalarını sağladığını ve bunun da kariyer uyumluluğunun geliştirilmesine yol açtığını göstermiştir. Proaktif kişiliğin başarılı olma ve kariyer uyumu arasında olumlu moderatör ilişkiye sahip olduğu ve bu ilişkinin proaktif kişilik özellikleri daha yüksek olan çalışanlar arasında daha güçlü olduğu bulunmuştur. Wechtler ve ark. (25) kar amac1 gütmeyen örgütlerde çalışan yabancı çalışanların kariyer değerleri ve kültürlerarası uyum arasındaki ilişkinin incelendiği çalışmada, otonomi, güvenlik, kendini adama ve meydan okuma değerinin genel yaşama uyum, teknik/fonksiyonel yetenek, yönetsel yetenek, meydan okuma ve enternasyonalizm değerinin iş uyumu ile olumlu ilişkili olduğu belirtilmiştir. $\mathrm{Bu}$ bulgular, modelde anlamlı etki gösteren girişimci ve meydan okuma değerini destekler niteliktedir. Güvenlik/istikrar puanı yüksek olan öğrencilerin daha fazla iş garantisi beklentisi ve özerklik/bağımsızlık puanı yüksek olan öğrencilerin çalışma ortamına uyum sağlayamayacağını düşünmeleri öğrencilerin kariyer geleceği algılarını negatif etkileyebilir. $\mathrm{Bu}$ değerlerin kariyer geleceğine etkisi gelecek araştırmalarda ve farklı örneklemlerde yeniden incelenmelidir.

\section{Sonuç}

$\mathrm{Bu}$ çalışmada, hemşirelik öğrencilerinin kariyer geleceği ve kariyer değerlerine ilişkin algılarının yüksek olduğu belirlendi. Kariyer geleceği puan ortalamasının yüksek olması, kariyer geleceğine ilişkin iyimser, uyumlu ve hazır olduğunu göstermektedir. Kariyer değerleri arasında en yüksek puan ortalaması kendini adama değerindedir, başkasına yardım etmeyi tanımlayan bu değer hemşireliğin doğası ile uyumludur. Kariyer değerleri ile kariyer geleceği arasında anlamlı zayıf ve orta düzeyde ilişki saptandı. Kariyer geleceği üzerine kariyer değerlerinden güvenlik/istikrar ve özerklik/bağımsızlık değerlerinin negatif, girişimci ve meydan okuma değerlerinin ise pozitif ve anlamlı olarak etki edebileceği belirlendi. Bununla birlikte üniversite başarısının ve mesleği yapmayı düşünmenin pozitif ve anlamlı olarak etki edebileceği saptandı.

Öğrencilerin erken dönem kariyer evresi olarak mesleki eğitimleri süresinde ilgilerini, değerlerini ve yeteneklerini tanıması ve bu doğrultuda kariyer geleceğine hazırlanması önemlidir. Öğrencilere kariyer danışmanlığı hizmeti verilmesi eğitim kurumlarının akreditasyonu için karşılanması gereken bir gerekliliktir. Bu çalışmanın uygulamaya katkısı, kariyer danışmanlığında, öğrencinin kariyer geleceğine etki edebilecek kariyer değerlerinin ve diğer değişken-lerin dikkate alınmasıdır. Kariyer danışmanlığı, yalnızca hemşirelerin çalışma alanları hakkında bilgilendirilme olmayıp öğrencinin mesleki role ve çalışma alanına uygunluğunun değerlendirilmesini de içermelidir. Mezun olan ögrencilerin meslekte kalması ve mesleğini yap-maktan doyum alarak yüksek performans göstermesinin sağlanmas1 amaciyla eğitimleri süresinde öğrencilerin kariyer uyumluluğunun değerlendirilmesi ve geri bildirimlerle geliştirilmesi sağlanmalıdır.

\section{Kaynaklar}

1. Aytaç S, Keser A. Çalışma Yaşamında Kariyer PlanlamasıYönetimi Geliştirilmesi ve Sorunları. 3. Bask1, Kocaeli: Umuttepe Yayınlari; 2017.

2. Siyez DM, Yusupu R. Üniversite öğrencilerinde kariyer uyumluluğu ve kariyer iyimserliğinin cinsiyet rolü değişkenine göre incelenmesi. İş, Güç, Endüstri İlişkileri ve İnsan Kaynakları Dergisi 2015; 17(1): 78-88.

3. Adıgüzel O, Erdoğan A. Anne Roe ve Holland'ın kişilik kuramları ile Shein'in kariyer değerlerinin içerik analizi yöntemiyle değerlendirilmesi. Uluslararası Alanya İşletme Fakültesi Dergisi 2014; 6(3):15-25.

4. Savickas ML. Career adaptability: An integrative construct for life span, life-space theory. The Career Development Quarterly 1997;45: 247259. 
5. Duffy RD. Sense of control and career adaptability among undergraduate students. Journal of Career Assessment 2010; 18(4): 420430.

6. Kalafat T. Kariyer Geleceği Ölçeği (KARGEL): Türk örneklemi için psikometrik özelliklerinin incelenmesi. Türk Psikolojik Danışma ve Rehberlik Dergisi 2012; 4 (38), 169-179.

7. Adıgüzel O. Shein'in kariyer çapaları perspektifinde Süleyman Demirel Üniversitesi İ̈BF öğrencilerinin kariyer değerlerine ilişkin bir araştırma. Süleyman Demirel Üniversitesi İktisadi ve İdari Bilimler Fakültesi Dergisi 2009; 14(2): 277-292.

8. Pala A. Öğrencilerin kariyer değerlerini etkileyen faktörler: Spor bilimleri fakültesi örneği. International Journal of Human Sciences 2016; 13(1), 1897-1905.

9. Bayram N, Gürsakal S, Aytaç S. Öğrencilerinin kariyer değerlerini açıklamada kişiliğin etkisi. Anadolu Üniversitesi Sosyal Bilimler Dergisi; 2012; 12(2): 181-190.

10. İbicioğlu H, Adıgüzel O, Öztürk UC. Kariyer danışmanlığını bir sonraki aşamaya taşımak: süreç danışmanlığı perspektifinde kariyer çapaları kullanımı ve bir uygulama. Uluslararası Yükseköğretim Kongresi: Yeni Yönelişler ve Sorunlar Bildiri Kitab1 Cilt 3, İstanbul: T.C. Yükseköğretim Kurulu; 2011: 1928-1935.

11. Eyüboğlu G. Evaluation of the university students' career anchors. İstanbul: Marmara Üniversitesi Sosyal Bilimler Enstitüsü; 2006.

12. Gezen T, Köroğlu Ö. Turizm eğitimi alan öğrencilerin kariyer seçimine etki eden kariyer çapalarının belirlenmesine yönelik bir araştırma. Dokuz Eylül Üniversitesi Sosyal Bilimler Enstitüsü Dergisi 2014; 16(2), 213 234.

13. Kalafat T. Kariyer Geleceği Algısını Etkileyen Kişisel Faktörlerin Belirlenmesine Yönelik Bir Model Çalışması, Ankara: Ankara Üniversitesi Eğitim Bilimleri Enstitüsü; 2014.

14. Karakaya YE, Karataş Ö, Özdenk Ç, Karataş F. Üniversiteli sporcu öğrencilerin kariyer değeri algıları. Doğuş Üniversitesi Dergisi 2013;14(1):86-94.

15. Aktaş H. The Importance of Career Anchor Notion for an Effective Career Planning and an Example Application at the Turkish Air Force Undergraduate and Graduate Schools. İstanbul:
Marmara Üniversitesi Sosyal Bilimler Enstitüsü; 2004.

16. Karadaş A, Duran S, Kaynak S. Hemşirelik öğrencilerinin kariyer planlamaya yönelik görüşlerinin belirlenmesi. SDÜ Sağl1k Bilimleri Enstitüsü Dergisi 2017; 8(1):1-8.

17. Karagöz Y. SPSS 21.1 Uygulamalı Biyoistatistik, 1.basım, Nobel Akademik Yayıncılık; 2014: 698.

18. Boroğlu Yatangaç F. Kişilik Özelliklerine Bağl1 Olarak Hemşirelik ve Tip Fakültesi Öğrencilerinin Çalışacağı Uzmanlık Alanlarının Belirlenmesi, Adana: Çukurova Üniversitesi Sağlık Bilimleri Enstitüsü; 2010.

19. Kanten S. Kariyer uyum yetenekleri ölçeği: geçerlilik ve güvenilirlik çalışması. Süleyman Demirel Üniversitesi Sosyal Bilimler Enstitüsü Dergisi 2012; 2(16):191-205.

20. Kaplan R, Shmulevitzy C, Raviv D. Reaching the top: Career anchors and professional development in nursing. International Journal of Nursing Education Scholarship 2009; 6(1): 121.

21. Gergely E, Pierog A. Motivation, values, and career research among university students. Annals of the University of Oradea Economic Science Series 2016; 25(1): 933-943.

22. Serin E, Soran S, Kılıç AO. Üniversite öğrencilerinin kariyer değerlerinin eğitim süreleri açısından incelenmesi ve bir uygulama. Cumhuriyet Üniversitesi İktisadi ve İdari Bilimler Dergisi 2014; 15(1): 209-220.

23. Kula Ö, Adıgüzel O. Lisansüstü öğrencilerinin kariyer planlamalarına etki eden faktörler: Süleyman Demirel Üniversitesi Sosyal Bilimler Enstitüsü öğrencileri üzerine bir araştırma. Süleyman Demirel Üniversitesi İktisadi ve İdari Bilimler Fakültesi Dergisi 2015; 20(1): 291315.

24. Jiang Z. Proactive personality and career adaptability: The role of thriving at work. Journal of Vocational Behavior 2017; 98: 8597.

25. Wechtler H, Koveshnikov A, Dejoux C. Career anchors and cross-cultural adjustment among expatriates in a non-profit organization. Manag Int Rev 2017; 57: 277-305. 